\title{
Lipoprotein (a) and coronary heart disease: a prospective case- control study in a general population sample of middle aged men,
}

\author{
Annika Rosengren, Lars Wilhelmsen, Elsa Eriksson, Bo Risberg, Hans Wedel
}

\begin{abstract}
Objective-To examine the association between the serum lipoprotein (a) concentration and subsequent coronary heart disease.

Design-Prospective case-control study based on a six year follow up of a general population sample of men aged 50 at baseline in 1983-4. Serum samples were frozen at the time of the baseline examination and kept at $-70^{\circ} \mathrm{C}$ for six years, after which the lipoprotein (a) concentrations in the samples were measured in cases and controls.

Setting-City of Gothenburg, Sweden.

Subjects-26 Men, from a general population sample of 776 men, who had sustained a myocardial infarction or died of coronary heart disease during the six years and 109 randomly selected controls from the same sample who had remained free of myocardial infarction. In neither cases nor controls was there a history of myocardial infarction at baseline.
\end{abstract}

Main outcome measures-Proportion of myocardial infarction or deaths from coronary heart disease, or both, in relation to the serum lipoprotein (a) concentration.

Results-Men who suffered coronary heart disease had significantly higher serum lipoprotein (a) concentrations than controls (mean difference $105 \mathrm{mg} / 1 ; 95 \%$ confidence interval 18 to $192 \mathrm{mg} / \mathrm{l}$ ). Men with the highest fifth of serum lipoprotein (a) concentrations (cut off point $365 \mathrm{mg} / \mathrm{l}$ ) suffered a coronary heart disease rate which was more than twice that of men with the lowest four fifths of concentrations. Logistic regression analysis showed the serum lipoprotein (a) concentration to be significantly associated with coronary heart disease independently of other risk factors.

Conclusion-The serum lipoprotein (a) concentration in middle aged men is an independent risk factor for subsequent myocardial infarction or death from coronary heart disease.

\section{Introduction}

In recent years several case-control and angiographic studies have shown increased concentrations of serum lipoprotein (a) in men and women with coronary heart disease ${ }^{1-6}$ and cerebrovascular disease. ${ }^{278}$ Despite the recent upsurge in interest in this lipoprotein, however, its function remains largely unknown. ${ }^{9}$ It is assembled from low density lipoprotein and a large hydrophilic glycoprotein, apolipoprotein (a). The plasma lipoprotein (a) concentration is inherited as a quantitative genetic trait $^{10}$ with a skewed distribution in white populations. Concentrations may vary from near zero to over $1000 \mathrm{mg} / \mathrm{l}$. Lipoprotein (a) has been found in arterial walls, " and a positive correlation between the serum lipoprotein (a) concentration and concentrations of lipoprotein (a) in arterial walls has been found in patients with coronary bypass grafts. ${ }^{12}$ The recent discoveries that apolipoprotein (a) is strongly homologous to plasminogen ${ }^{1314}$ and that lipoprotein (a) and apolipoprotein (a) compete with plasminogen for binding to the plasminogen receptor ${ }^{1516}$ have stimulated further intensive research into the properties of this enigmatic lipoprotein.

There seems to be general agreement that lipoprotein (a) is associated with coronary atherosclerosis and myocardial infarction, but this has not been corroborated by prospective data. This study examines lipoprotein (a) concentrations in middle aged men who subsequently developed myocardial infarction during a follow up period of six years and compares these concentrations with those in controls of the same age who remained free of myocardial infarction.

\section{Subjects and methods}

In 1983 a random sample was drawn of half of all men in Gothenburg, Sweden, who were born in 1933 (that is, who were aged 50). All 1016 men in the sample were invited for a screening examination, and 776 $(76 \%)$ attended.

All examinations were performed in the morning. Blood pressure was measured with a mercury sphygmomanometer and with the subject sitting after five minutes' rest. Values were taken to the nearest $2 \mathrm{~mm} \mathrm{Hg}$. Body weight was measured on a lever balance and recorded to the nearest $0 \cdot 1 \mathrm{~kg}$. Body mass index was calculated as weight $(\mathrm{kg})$ divided by the square of the height $\left(\mathrm{m}^{2}\right)$.

All blood samples were taken after an overnight fast. Serum cholesterol and triglyceride concentrations were determined by standard methods using reference values of the World Health Organisation's laboratory in Prague. Plasma fibrinogen concentration was measured with a polymerisation method as originally described by Clauss. ${ }^{17}$ Additional blood samples were drawn from all study participants and the serum kept in sealed glass ampoules at $-70^{\circ} \mathrm{C}$ for six years. Serum samples from cases and controls (see below) were then thawed at $37^{\circ} \mathrm{C}$ and analysed for lipoprotein (a) concentrations. The ampoules were labelled with coded numbers, so that the identity of the subjects (and therefore their disease state) was unknown to the laboratory staff. Lipoprotein (a) concentration was determined at two dilutions with a Tint Elize $\mathrm{Lp}(\mathrm{a})$ kit from Biopool $\mathrm{AB}$ (Umeå, Sweden). The average variation between the two determinations was 3.9\% (SD 3.7\%). Between assay variations at lipoprotein (a) concentrations of $101 \mathrm{mg} / \mathrm{l}$ and $255 \mathrm{mg} / \mathrm{l}$ were $7 \cdot 2 \%$ and $3.9 \%$ respectively. In a subsample lipoprotein (a) concentration was also determined with an immunoradiometric assay from Pharmacia (Uppsala, Sweden), but as the two methods correlated well only data from the first method are presented.

All participants completed a postal questionnaire concerning smoking habits and family history of cardiovascular disease and the answers were checked by the examining physician. Additional inquiries concerned the presence of diabetes, past or present treatment for hypertension, and admission to hospital for myocardial infarction before the examination. A history of myocardial infarction in the mother or father was coded as present if the subject had answered yes to this question and as absent if the subject had answered no or did not know.

Gothenburg, Sweden. 
All non-fatal cases of myocardial infarction in Gothenburg are recorded according to specific criteria.$^{18}$ Death certificates for the men in the study are collected routinely. By the end of the six years $(31$ December 1989) 31 of the 776 participants in the study had either suffered a non-fatal myocardial infarction $(n=22)$ or died of coronary heart disease $(n=9)$.

For each man who had suffered a myocardial infarction or died of coronary heart disease during follow up four controls were selected at random from the rest of the study participants. All men with a history of previous myocardial infarction (four cases, two controls) or with incomplete data $(11$ blood samples destroyed during thawing, data on other risk factors missing for three men) were excluded, leaving a total of 26 cases and 109 controls for analysis. Of the 26 cases, five were deaths from coronary heart disease and 21 were non-fatal myocardial infarctions.

Statistical methods-A $t$ test was used to examine differences between cases and controls in respect of continuous variables. Odds ratios with $95 \%$ confidence intervals were calculated to illustrate differences between cases and controls in respect of non-continuous variables. Pearson correlation coefficients were determined for the association between lipoprotein (a) concentrations and other risk factors. Logistic regression applied to this nested case-control study was used to adjust associations for the influence of other covariables. Unconditional likelihood estimates were calculated as measures of the association between risk factors and coronary heart disease. ${ }^{19}$ Two tailed tests were used and $\mathrm{p}$ values below 0.05 considered significant.

\section{Results}

Tables I and II present the risk factors for coronary heart disease analysed in the cases and controls. The serum lipoprotein (a) concentration was significantly higher in the cases than in controls $(277.7 \mathrm{mg} / \mathrm{l} v$ $172.7 \mathrm{mg} / \mathrm{l}$; mean difference $105.0 \mathrm{mg} / \mathrm{l}(95 \%$ confidence interval 18.0 to $192.0 \mathrm{mg} / \mathrm{l})$ ). Both serum triglyceride and serum cholesterol concentrations were higher in the cases. There were twice as many smokers among the cases as among the controls (table II). A maternal history of myocardial infarction and past or present treatment for hypertension were more common among the cases than among the controls, but neither systolic nor diastolic blood pressure (not shown) was significantly raised among the cases. Of the eight cases in which there was a history of hypertension, four were in men being treated with $\beta$ blockers, one was in a man

TABLE I-Physical and laboratory coronary risk factors in cases and controls

\begin{tabular}{|c|c|c|c|}
\hline & \multicolumn{2}{|c|}{ Mean value $(\mathrm{SD})$} & \multirow{2}{*}{$\begin{array}{c}\text { Mean difference } \\
\text { (95\% confidence interval }\end{array}$} \\
\hline & Cases $(n=26)$ & Controls $(n=109)$ & \\
\hline Systolic blood pressure $(\mathrm{mm} \mathrm{Hg})$ & $134 \cdot 5(18 \cdot 9)$ & $133 \cdot 2(16 \cdot 9)$ & $1 \cdot 3(-6 \cdot 3$ to $8 \cdot 9)$ \\
\hline Serum cholesterol $(\mathrm{mmol} / \mathrm{l})$ & $6 \cdot 7(1 \cdot 2)$ & $6 \cdot 2(1 \cdot 2)$ & $0.5(0.01$ to 1.1$)$ \\
\hline Serum triglycerides $(\mathrm{mmol} / \mathrm{l})$ & $2 \cdot 0(1 \cdot 8)$ & $1.4(1 \cdot 0)$ & $0.6(0.06$ to 1.1$)$ \\
\hline Plasma fibrinogen $(\mathrm{g} / \mathrm{l})^{\star}$ & $3 \cdot 5(1.0)$ & $3 \cdot 2(0 \cdot 8)$ & $0 \cdot 3(-0 \cdot 1$ to $0 \cdot 7)$ \\
\hline Serum lipoprotein (a) (mg/l) & $277 \cdot 7(273 \cdot 9)$ & $172 \cdot 7(177 \cdot 7)$ & $105 \cdot 0(18 \cdot 0$ to $192 \cdot 0)$ \\
\hline Body mass index $\left(\mathrm{kg} / \mathrm{m}^{\prime}\right)$ & $26 \cdot 6(3 \cdot 1)$ & $25 \cdot 4(3 \cdot 1)$ & $1 \cdot 2(-0.1$ to $2 \cdot 5)$ \\
\hline Waist to hip ratio & $0.95(0.05)$ & $0.93(0.06)$ & $0.02(-0.01$ to 0.04$)$ \\
\hline
\end{tabular}

${ }^{\star}$ Data missing in four cases and 12 controls.

TABLF II - Odds ratios for clinical coronary risk factors in cases and controls

\begin{tabular}{lccc}
\hline & $\begin{array}{c}\%(\mathrm{No}) \text { of cases } \\
(\mathrm{n}=26)\end{array}$ & $\begin{array}{c}\%(\mathrm{No}) \text { of controls } \\
(\mathrm{n}=109)\end{array}$ & $\begin{array}{c}\text { Odds ratio } \\
(95 \% \text { confidence interval })\end{array}$ \\
\hline $\begin{array}{l}\text { Smokers } \\
\text { History of myocardial infarction } \\
\text { in mother }\end{array}$ & $65 \cdot 4(17)$ & $32 \cdot 1(35)$ & $4 \cdot 0(1 \cdot 6$ to $9 \cdot 8)$ \\
$\begin{array}{l}\text { History of myocardial infarction } \\
\text { in father }\end{array}$ & $19 \cdot 2(5)$ & $5 \cdot 5(6)$ & $4 \cdot 1(1 \cdot 1$ to $14 \cdot 6)$ \\
$\begin{array}{l}\text { Treatment for hypertension } \\
\text { Diabetes }\end{array}$ & $19 \cdot 2(5)$ & $23 \cdot 9(26)$ & $0 \cdot 8(0 \cdot 3$ to $2 \cdot 2)$ \\
& $30 \cdot 8(8)$ & $8 \cdot 3(9)$ & $4 \cdot 9(1 \cdot 7$ to $14 \cdot 5)$ \\
& $11 \cdot 5(3)$ & $7 \cdot 3(8)$ & $1 \cdot 6(0 \cdot 4$ to $6 \cdot 7)$ \\
\hline
\end{tabular}

TABLE III - Coronary heart disease events during six years of follow up by fifth of lipoprotein $(a)$ concentrations

\begin{tabular}{lc}
\hline Fifth of lipoprotein (a) concentration & $\begin{array}{c}\% \text { (No) of subjects with } \\
\text { coronary heart disease events }\end{array}$ \\
\hline$[1]<38 \mathrm{mg} / \mathrm{l}(\mathrm{n}=27)$ & $11 \cdot 1(3)$ \\
{$[2] 38=75 \mathrm{mg} / \mathrm{l}(\mathrm{n}=27)$} & $25 \cdot 9(7)$ \\
{$[3] 75-140 \mathrm{mg} / \mathrm{l}(\mathrm{n}=27)$} & $11 \cdot 1(3)$ \\
{$[4] 140-365 \mathrm{mg} / \mathrm{l}(\mathrm{n}=27)$} & $11 \cdot 1(3)$ \\
{$[5]>365 \mathrm{mg} / \mathrm{l}(\mathrm{n}=27)$} & $37 \cdot 0(10)$ \\
\hline$\beta^{\star}$ & $0 \cdot 0023$ \\
$\mathrm{SE}$ & $0 \cdot 0010$ \\
$\mathrm{p}$ Value & $0 \cdot 022$
\end{tabular}

${ }^{\star}$ Obtained by logistic regression (unadjusted for other variables).

TABLE IV-Multiple logistic regression of coronary heart disease during six years

\begin{tabular}{lccc}
\hline Variable & $\beta$ & $\mathrm{SE}$ & $\mathrm{p}$ Value \\
\hline Serum cholesterol $(\mathrm{mmol} / \mathrm{l})$ & $0 \cdot 124$ & 0.202 & 0.54 \\
Body mass index $\left(\mathrm{kg} / \mathrm{m}^{2}\right)$ & 0.179 & 0.079 & 0.023 \\
History of myocardial infarction in & & & \\
$\quad$ mother (yes $v$ no) & 1.573 & 0.764 & 0.039 \\
Smoking (yes $v$ no) & 1.405 & 0.545 & 0.010 \\
Treatment for hypertension (yes $v$ no) & 1.451 & 0.636 & 0.023 \\
Serum lipoprotein $(\mathrm{a})(\mathrm{mg} / \mathrm{l})$ & 0.0031 & 0.0012 & 0.010 \\
\hline
\end{tabular}

taking a saluretic, and three were in men who were not currently being treated. Eight of the nine controls with hypertension were receiving $\beta$ blockers. Plasma fibrinogen concentration, body mass index, waist to hip ratio, paternal history of myocardial infarction, and diabetes were not significantly associated with coronary heart disease.

Further to determine the relation between coronary heart disease and the serum lipoprotein (a) concentration the cases and controls were divided into fifths of lipoprotein (a) values (table III). The association was slightly irregular, both the second and highest fifths of values being associated with a high proportion of cases. Among the seven cases in men with the second fifth of values, however, five were in smokers, whereas among the 10 cases in men with the highest fifth of values only four were in smokers. The proportion of cases of coronary heart disease in men with the highest fifth of values was more than twice that in men with the lowest four fifths of values considered together.

There was a positive correlation between the serum cholesterol concentration and the serum lipoprotein (a) concentration $(\mathrm{r}=0.18 ; \mathrm{p}=0.04)$ and between systolic blood pressure and the serum lipoprotein (a) concentration $(r=0.17 ; p=0.05)$. There were no other significant relations between lipoprotein (a) value and risk factors, including smoking, body mass index, and hypertension. A history of myocardial infarction in the mother was twice as common in men with the highest fifth of lipoprotein (a) concentrations, but this difference was not significant $(p=0 \cdot 37)$.

Table IV gives the results of a multiple logistic regression analysis with coronary heart disease as the dependent variable and cholesterol concentration, body mass index, maternal history of myocardial infarction, smoking, treatment for hypertension, and serum lipoprotein (a) concentration as independent variables. Lipoprotein (a) concentration remained independently associated with coronary heart disease. Substituting triglyceride concentration for cholesterol concentration did not alter the results.

Of the 26 cases of coronary heart disease, only nine were in non-smokers; six of these were among the group with the highest fifth of serum lipoprotein (a) concentrations. Thus 23 of the 26 cases of coronary heart disease were characterised by occurring in smokers or men with raised serum lipoprotein (a) concentrations, or both. Of the remaining cases, one was in a diabetic subject and one in a man with uncontrolled hypertension at the time of screening. 


\section{Discussion}

This prospective study has shown an association between the serum lipoprotein (a) concentration and subsequent coronary heart disease in a general population sample of middle aged men and confirms earlier, retrospective case-control studies. ${ }^{1-6}$ The serum lipoprotein (a) concentration was significantly higher in patients with myocardial infarction who subsequently suffered reinfarction than in patients with myocardial infarction who did not, ${ }^{20}$ but this effect was not independent in multivariate analysis. Confirmation by prospective data of results obtained by retrospective case-control studies is necessary as the event in itself may alter the factor under study. Also fatal cases may be lost in a retrospective study. The serum lipoprotein (a) concentration has recently been shown to increase dramatically within the first few days after an acute myocardial infarction and to return to initial values after more than a month. ${ }^{21}$ In several case-control studies blood samples were taken more than six months after the event, when lipoprotein (a) concentrations would have returned to normal. Even so, without confirmation by prospective data this issue will remain unresolved.

Both the cases and the controls in this study were from the same general population sample. This means that after some easily performed corrections to adjust for the disproportionate number of cases of coronary heart disease in the study group the results may be regarded as representative of the background population of middle aged men in Gothenburg. Though it would have been preferable to perform the analyses of lipoprotein (a) concentrations in all the participants in the study, this was not possible, mainly for financial reasons.

The serum samples used for analysis of lipoprotein (a) concentrations had been kept frozen for six years. We are not aware of any data on the stability of lipoprotein (a) values in samples frozen for such a long time. The mean lipoprotein (a) concentration of our controls $(172.7 \mathrm{mg} / \mathrm{l})$, however, compared well with that of another Swedish population sample of men and women aged $50-60(151 \cdot 7 \mathrm{mg} / \mathrm{l}) .^{22}$

Unlike other researchers ${ }^{2324}$ we did not find a strong association between high lipoprotein (a) concentrations in our subjects and coronary heart disease in parents, even though a maternal history of myocardial infarction was an independent risk factor for coronary heart disease in its own right. Our subjects, however, were middle aged men with parents at least in their $70 \mathrm{~s}$. We did not specify early myocardial infarction in the parents, which may account for the differences in comparison with other surveys. Also the disease state of the father was known in only 20 of the 26 cases in the study.

The serum lipoprotein (a) concentration seems to be largely unrelated to other risk factors with the exception of the cholesterol concentration. Part of this association is due to the cholesterol content of lipoprotein (a). It has been suggested that the association between coronary heart disease and serum lipoprotein (a) concentration is dependent on serum low density lipoprotein values. ${ }^{3}$ High density lipoprotein concentrations were not measured in this study, and consequently this issue could not be examined. As the number of cases in our study was small we could not make any reliable estimates of the effect of lipoprotein (a) at different cholesterol concentrations. A recent study has shown a raised lipoprotein (a) concentration to be significantly associated with evidence of coronary heart disease in patients with familial hypercholesterolaemia..$^{25}$ The impact of a raised serum lipoprotein (a) concentration in samples with a low cholesterol concentration awaits further clarification by prospective data.
What are the public health implications of our findings? If the distribution of lipoprotein (a) values in the control group is taken to be representative of the total study group $(n=757)$ the population attributable fraction may be calculated as $27 \%$ of all cases (seven extra cases in the group with the high lipoprotein (a) concentrations). Interestingly, the only other study which has considered population attributable risk for raised lipoprotein (a) concentrations (albeit with a lower cut off point for lipoprotein (a) concentration) reached almost exactly the same conclusion-namely, one in four myocardial infarctions in men under $60 .{ }^{4}$

The attributable fraction of $27 \%$ should be compared with the population attributable fraction for smoking, which was $46 \%$ for all participants in the study. Even though serum lipoprotein (a) concentrations have been shown to respond to pharmacological agents, ${ }^{26}$ it is unknown whether this influences outcome. Modifying the diet does not seem to lower the serum lipoprotein (a) concentration. ${ }^{27}$ In the absence of effective and harmless measures of intervention mass screening of lipoprotein (a) concentrations in the population is not warranted. In clinical practice, however, determining the lipoprotein (a) concentration may be useful in decisions about treatment for patients with other risk factors. The association between coronary heart disease and the lipoprotein (a) concentration at different levels of other cardiovascular risk factors remains to be determined in larger prospective studies.

This study was supported by the Swedish Medical Research Council (project 00660), the Swedish National Association Against Heart and Chest Diseases, the Gothenburg Medical Society, and the Knut and Alice Wallenberg Foundation.

1 Kostner GM, Avogaro P, Cazzolato G, Marth E, Bittolo G, Qunici GB. Lipoprotein $\mathrm{LP}(\mathrm{a})$ and the risk for myocardial infarction. Atherosclerosis 1981;38:51-61.

2 Murai A, Miyahara T, Fujimoto N, Matsuda M, Kameyama M. Lp(a) lipoprotein as a risk factor for coronary heart disease and cerebral infarction. Atherosclerosis 1986;59:199-204.

3 Armstrong VW, Cremer P, Eberle E, et al. The association between serum $\mathrm{Lp}$ (a) concentrations and angiographically assessed coronary atherosclerosis. Dependence on serum LDL levels. Atherosclerosis 1986;62:249-57.

4 Rhoads GG, Dahlén G, Berg K, Morton NE, Dannenberg AL. Lp(a) lipoprotein as a risk factor for myocardial infarction. JAMA 1986;256:2540-

5 Dahlén GH, Guyton JR, Attar M, Farmer JA, Kautz JA, Gotto AM. Association of levels of lipoprotein(a), plasma lipids, and other lipoproteins with coronary artery disease documented by angiography. Circulation 1986;74:758-65.

6 Sandkamp M, Funke H, Schulte H, Köhler E, Assman G. Lipoprotein(a) is an independent risk factor for myocardial infarction at a young age. Clin Chem 1990;36:20-3

7 Jürgens G, Költringer P. Lipoprotein(a) in ischemic cerebrovascular disease: a new approach to the assessment of risk for stroke. Neurology 1987;37:513-5.

8 Zenker $G$, Költringer $P$, Boné $G$, Niederkorn K, Pfeiffer K, Jürgens G. Lipoprotein(a) as a strong indicator for cerebrovascular disease. Stroke
Liser Lipoprotein(a)

9 Utermann G The mysteries of lipoprotein(a). Science 1989:246:904-10.

10 Utermann G, Menzel HJ, Kraft HG, Duba HC, Kemmler HG, Seitz C. Lp(a) glycoprotein phenotypes. Inheritance and relation to $\mathrm{Lp}(\mathrm{a})$-lipoprotein concentrations in plasma. 7 Clin Invest 1987;80:458-65.

11 Walton KW, Hitchens J, Magnani HN, Khan M. A study of methods of identification and estimation of $\mathrm{Lp}(\mathrm{a})$ lipoprotein and of its significance in health, hyperlipidaemia and atherosclerosis. Atherosclerosis 1974;20:323-46.

12 Rath M, Niendorf A, Reblin T, Dietel M, Krebber HJ, Beisiegel U. Detection and quantification of lipoprotein(a) in the arterial wall of 107 coronary by pass patients. Arteriosclerosis 1989;9:579-92.

13 Eaton DL, Fless GM, Kohr WJ, et al. Partial amino acid sequence of apolipoprotein(a) shows that it is homologous to plasminogen. Proc Natl Acad SciU S A 1987;84:3224-8.

14 McLean JW, Tomlinson JE, Kuang WJ, et al. cDNA sequence of human apolipoprotein(a) is homologous to plasminogen. Nature 1987;330:132-7.

15 Edelberg JM, Gonzalez-Gronow M, Pizzo SV. Lipoprotein a inhibits streptokinase-mediated activation of human plasminogen. Biochemistry 1989;28: 2370-4

16 Gonzalez-Gronow M, Edelberg JM, Pizzo SV. Further characterization of the cellular plasminogen binding site: evidence that plasminogen 2 and lipoprotein(a) compete for the same site. Biochemistry 1989;28:2374-7.

17 Clauss A. Gerinnungsphysiologische Schnellmethode zur Bestimmung des Fibrinogens. Acta Haematol (Basel) 1957;17:237.

18 Elmfeldt D, Wilhelmsen L, Tibblin G, Vedin A, Wilhelmsson C, Bengtsson C. Registration of myocardial infarction in the city of Göteborg, Sweden. Journal of Chronic Diseases 1975;28:173-86.

19 Kleinbaum DG, Kupper LL, Morgenstern H. Logistic regression analysis. In: Epidemiologic research: principles and quantitative methods. Belmont, California: Lifetime Learning Publications, 1982:ch 20:3.

20 Hamsten A, de Faire $\mathrm{U}$, Walldius $\mathrm{G}$, et al. Plasminogen activator inhibitor in plasma: risk factor for recurrent myocardial infarction. Lancet 1987;ii:3-9. 
21 Maeda S, Abe A, Seishima M, Makino K, Noma A, Kawade M. Transien changes of serum lipoprotein(a) as an acute phase protein. Atherosclerosis 1989;78:145-50

22 Sundell IB, Nilsson TK, Hallmans G, Hellsten G, Dahlén GH. Interrclationships between plasma levels of plasminogen activator inhibitor, tissue plasminogen activator, lipoprotein(a) and established cardiovascular risk factors in a north Swedish population. Atherosclerosis 1989;80:9-16.

23 Durrington PN, Ishola M, Hunt L, Arrol S, Bhatnagar D. Apolipoprotein (a) AI, and B and parental history in men with early onset ischaemic hear disease. Lancet 1988; i: 1070-3.

24 Hoefler G, Harnoncourt F, Paschke E, Mirtl W, Pfeiffer KH, Kostner GM Lipoprotein Lp(a). A risk factor for myocardial infarction. Arteriosclerosis 1988:8:398-401.
25 Seed M, Hoppichler F, Reaveley D, et al. Relation of serum lipoprotein(a) concentration and apolipoprotein (a) phenotype to coronary heart disease in patients with familial hypercholesterolemia. $N$ Engl f Med 1990;322: $1494-9$

26 Carlson LA, Hamsten A, Asplund A. Pronounced lowering of serum levels of lipoprotein(a) in hyperlipidaemic subjects treated with nicotinic acid F Intern Med 1989;226:271-6.

27 Masarei JRL, Rouse IL, Lynch WJ, Robertson K, Vandongen R, Beilin LJ. Effects of a lacto-ovovegetarian diet on serum concentrations of cholesterol, triglyceride, $\mathrm{HDL}-\mathrm{C}, \mathrm{HDL}_{2}-\mathrm{C}, \mathrm{HDL}_{3}-\mathrm{C}$, apoprotein-B and $\mathrm{Lp}(\mathrm{a}) . A m \mathcal{f}$ Clin Nutr 1984;40:468-79.

(Accepled 11 Seplember 1990)

\title{
Ear wax removal: a survey of current practice
}

\author{
J F Sharp, Janet A Wilson, Linda Ross, R M Barr-Hamilton
}

TABLE I - Number of patients presenting for ear wax removal to 289 general practitioners

\begin{tabular}{lc}
\hline $\begin{array}{l}\text { Patients seen } \\
\text { per month }\end{array}$ & $\begin{array}{c}\text { No of general } \\
\text { practitioners }\end{array}$ \\
\hline $0-5$ & 7 \\
$6-10$ & 133 \\
$11-20$ & 101 \\
$21-50$ & 31 \\
$\geqslant 51$ & 4 \\
No reply & 13 \\
\hline
\end{tabular}

\section{Department of}

Otolaryngology, Royal

Infirmary, Edinburgh EH3 9EN

J F Sharp, FRCSED, registrar

Janet A Wilson, FRCSED, senior registrar

Linda Ross, SRN, sister

Department of Audiology, Royal Infirmary, Edinburgh EH3 9EN

R M Barr-Hamilton, PHD, principal audiological scientist

Correspondence to: $\mathrm{Dr}$ Sharp.

BrMed F 1990;301:1251-3

\section{Abstract}

Objective-Todetermine the methods of removing ear wax used by local general practitioners and the incidence of associated complications.

Design-Postal survey of 312 general practitioners serving a population of about 650000 ; supplementary study of ear, nose, and throat outpatients to quantify the improvement in aural acuity after wax removal.

Setting-Catchment area of the Edinburgh otolaryngological unit.

Participants-289 General practitioners who responded to the survey; 21 outpatients in the ear, nose, and throat department with occlusive wax.

Results-274 General practitioners removed wax by syringing, but only $53(19 \%)$ always performed the procedure themselves; the remainder routinely delegated the task to practice nurses, some of whom had received no instruction. Ears were rarely examined again after the procedure. Complications had been experienced by 105 practitioners (38\%) and included perforation, canal lacerations, and failure of wax removal. The removal of occlusive wax improved hearing by a mean of $5 \mathrm{~dB}$ over the frequencies analysed.

Conclusions-About 44000 ears are syringed each year in the area and complications requiring specialist referral are estimated to occur in 1/1000 ears syringed. The incidence of complications could be reduced by a greater awareness of the potential hazards, increased instruction of personnel, and more careful selection of patients.

\section{Introduction}

Ear wax removal is the otolaryngological procedure most commonly performed by general practitioners and is their commonest source of iatrogenic otolaryngological problems. ${ }^{1}$ Modern otolaryngological textbooks do not often refer to ear syringing, ${ }^{2}$ and the indications and optimum methods for aural wax removal are not known. Wax may cause tinnitus or otalgia and removal may be required to allow adequate otoscopic examination, but many patients with a sensorineural hearing loss request repeated ear syringings in the mistaken belief that these will restore auditory acuity. Potential complications include perforation, otitis externa, vertigo, and cardiac arrest. ${ }^{3}$ We have recently seen several outpatients from the ear, nose, and throat department who had complications of ear syringing, including a temporal lobe abscess. This prompted a survey of the methods of ear wax removal and the incidence of complications in the community.

\section{Methods}

A postal survey was carried out in the Lothian area. Three hundred and twelve general practitioners serving a population of about 650000 were questioned. Doctors were asked to complete a short questionnaire with items on the number and selection of patients seeking wax removal, the methods used, complications encountered, and respondent's perception of any effect on auditory acuity. A supplementary survey to quantify the degree of improvement in auditory acuity after wax removal was conducted in the ear, nose, and throat outpatient clinic. Twenty one unselected outpatients who presented with completely occlusive aural wax were assessed by pure tone audiometry before and after wax removal by syringing. The ears were inspected after syringing and any residual water removed. The audiometric testing was performed according to the recommended procedures of the British Society of Audiology. The effect of syringing on aural acuity was measured by determining hearing thresholds at 250 and $500 \mathrm{~Hz}$ and 1,2 , and $4 \mathrm{kHz}$ before and after wax removal. A paired $t$ test comparing the means of the five frequencies was then performed.

\section{Results}

The 289 replies received (92\% of the study group) indicated that each doctor saw an average of nine patients (range five to 50 or more) requesting the removal of ear wax per month (table I). The initial medical assessment was made by 179 general practitioners $(62 \%)$. No medical assessment was made by $23(8 \%)$; these patients were referred directly to the practice nurse. The remaining $87(30 \%)$ offered examination by either the doctor or nurse. Table II shows the variety of ceruminolytic agents used.

As expected, syringing was the most common method of removal and was used by 274 general practitioners $(95 \%)$. Twelve $(4 \%)$ used instrumentation (a Jobson Horne probe) as their initial method of wax removal. Three (1\%) referred their patients directly to the outpatient clinic. Only 53 general practitioners (19\%) always performed the syringing procedure themselves; the practice nurse routinely syringed the ears of all patients referred to 73 general practitioners $(27 \%)$. The remaining 148 practitioners

TABLE II -Ceruminolytics prescribed by general practitioners (55 used several preparations)

\begin{tabular}{lcc}
\hline Preparation & $\begin{array}{c}\text { No of general } \\
\text { practitioners }\end{array}$ & Unit cost (pence) \\
\hline Oil & 233 & 7 \\
Cerumol & 43 & 83 \\
Bicarbonate & 27 & 2 \\
Exterol & 10 & 235 \\
Waxsol & 6 & 86 \\
Soliwax & 5 & 73 \\
Earex & 3 & \\
"Proprietary preparation" & 3 & 79 \\
Glycerine & 1 & \\
None & 13 & \\
\end{tabular}

